\title{
ONTOLOGY OF UBIQUITOUS LEARNING: WHATSAPP MESSENGER COMPETES SUCCESSFULLY WITH LEARNING MANAGEMENT SYSTEMS (LMS) IN GHANA
}

\author{
William K. Koomson \\ PhD. Valley View University, Dodowa Rd, Oyibi, Accra. Ghana
}

\begin{abstract}
The purpose for this study was to add to the body of research and to further examine how mobile learning can help remedy the limitations e-learning poses for students who live in Ghana with lack of access to electrical power and internet connectivity issues. Qualitative approach was employed with a total sample size of 807 students, composed of 58 percent male and 42 percent female. When the question was asked about students' willingness to purchase a new mobile device if they thought it would improve their performance at school; 87 percent indicated "yes." About 95 percent of the students indicated that having course materials such as lecture notes, practice quizzes, videos, and PowerPoints available on their mobile devices would be beneficial for their study process. The participants stated that they would be comfortable to allow their lecturers to contact them through their mobile devices. They also indicated that, apart from using their mobile phones to make and receive calls, texting using WhatsApp Messenger was the activity they often engaged in with their mobile phones. In this study, I made several assertions that, for WhatsApp Messenger to work properly in any classroom in Ghana, there must be intentional designs and step-by-step approach to teach both the faculty and the students how to use the application to achieve the utmost outcomes. I, therefore, concluded that using WhatsApp Messenger in a blended mobile learning context may help resolve many of the contextual difficulties that plague students in a e-learning situation in Ghana.
\end{abstract}

\section{KEYWORDS}

Ubiquitous Learning, Blended e-Learning, Connectivity, Mobile-Learning

\section{INTRODUCTION}

The evolution of the Third Generation Web and smartphone applications which have been created to run on mobile devices of the $21^{\text {st }}$ Century have transformed the entire universe in all areas, including the way we communicate, function, in our daily living, and even the way we study. Almost every corner of the universe, including developing countries such as, sub-Saharan Africa, South Asia, and South America, use these technologies for transactional purposes. Farmers use these applications (apps) to transact farm businesses; communities use them to preserve family traditions and memories; and business executives are able to bridge transactional gaps. Meanwhile, researchers acquire access to research artifacts through apps, and teachers engage their students in the classrooms using these innovative technologies.

Mobile technologies with cellular connectivity continue to dominate the information communication technology market in sub-Saharan Africa. Prior to the advent of mobile phones, many sub-Saharan African countries whose citizens lived in the most remote parts of the country were cut-off regarding the use of telephones, powered by landlines to connect to the global world. However, the abundance of the mobile network systems has changed the face of telecommunication and has transformed the way business is transacted in sub-Saharan Africa and the rest of the developing world. Citizens are able to skip the landline developmental stage of telecommunication to digitalization.

According to the Pew Research Center (2015), cell phone usage in Africa pales in comparison to that of developed countries like the United States of America. However, there has been a dramatic surge in the growth of smartphone usage in sub-Saharan Africa. As of 2014, the following countries recorded high percentages of cell phone usage; Uganda 65\%, Tanzania 73\%, Kenya 82\%, Ghana 83\%, and South Africa, $89 \%$. In the same year, the United States' cell phone usage was $89 \%$, the same as in South Africa and only in 
single-digits, higher than Ghana and Kenya. Among the many uses of cell phones in Africa for a twelve-month period, texting was the most (Pew Research Center, 2015).

Joy Online (2013) reported that Ghana was ranked by the International Telecoms Union Report as number one in Africa with more people using or connected to mobile broadband. Laary (2016) stated that for the period ending December 2015, Ghana's mobile phone voice penetration rate surged to $128 \%$, far above earlier projections by telecommunication experts. The adoption of mobile technology with its diverse apps can serve as a conduit for mobile learning.

\section{RELATED WORK}

The objective of this paper was to create an ontology to demonstrate new approaches to study and understand mobile learning through the use of WhatsApp Messenger as a learning tool in a distance learning program. The goal was to add to the body of research and further study how mobile learning can help to remedy the limitations online learning poses for students who live in sub-Saharan Africa with lack of access to electrical power and internet connectivity issues. Motlik (2008) suggested that, mobile learning will pave the way for online learning as the internet is not stable and is unavailable in many parts of rural areas in developing nations. Also mobile learning is more affordable to less developed nations and financially constrained groups (Gronlund \& Islam, 2010).

Notwithstanding these positive developments, some, including academics in higher education in sub-Saharan Africa, refuse to accept the fact that online learning can be done through mobile devices. They still believe that because of the unstableness of Internet connectivity, few institutions of formal learning can successfully go online in sub-Saharan Africa, including Ghana (Yeboah \& Ewur, 2014). However, with mobile learning technologies like "WhatsApp Messenger," developing countries have no excuses as to why they are not able to adopt online learning in the remotest parts of the country where connectivity is a major setback. Everywhere a mobile phone is used, whether for WhatsApp, Email, SMS, video or photo sharing, online learning is possible. In the academic environments, just as in the community, households and business places, WhatsApp Messenger has been used to create group chats for work teams, social networking, and learning.

In Ghana, the most common format adopted in Distance Learning is the tutorial format, where very few online interactions occur; in most instances, there are no online interactions. The universities that enroll their students through the distance learning mode, rely heavily on print materials in the form of course modules and students meet regularly during weekends in tutorial centers throughout the nation where they receive face-to-face instructions. Very few programs include videos and voice presentations in their distance learning pedagogy (Larkai, Ankomah-Asare, \& Nsowah-Nuamah, 2016; Yeboah \& Ewur, 2014).

\subsection{Mobile Learning}

UNESCO (2013) defines mobile learning (m-Learning) as involving; "the use of mobile technology, either alone or in combination with other information and communication technology (ICT), to enable learning anytime and anywhere. Learning can unfold in a variety of ways: people can use mobile devices to access educational resources, connect with others, or create content, both inside and outside classrooms (p. 6). Quin (2001) also defines m-Learning as learning that is done through mobile computational devices, such as "Palms, Windows CE machines, even your digital cell phone."

UNESCO has compiled many unique benefits of mobile learning. Among the list are; 1). Reach and equity of education - making learning accessible to people in the world who would otherwise be cut out from receiving education via online learning; 2). Personalized learning - learners can carry their mobile devices to and from places of employment, schools, bedrooms, boardrooms, and to recreational venues; 3). Provides immediate feedback and assessment - allowing learners to quickly pinpoint problems of understanding and review explanations of key concepts; 4). Productive use of time spent in classrooms - students can learn anywhere anytime; 5). Build new communities of learners. 6). Support situated learning; 7). Enhance seamless learning - students can access learning materials from wide varieties of devices; 8). Bridge formal and informal learning; 9). Minimize educational disruption in conflict and disaster areas; 10). Assist learners with disabilities; 11). Improve communication and administration; and 12). Maximize cost-efficiency by leveraging technology students already own, rather than providing new devices that are not tested (UNESCO, 2013, p. 10-26). 


\subsection{WhatsApp Messenger for m-Learning}

Research on the application of WhatsApp Messenger in the classroom is new and developing, however, its usage as a social media tool on smartphones is widespread (Cetinkaya, 2017; Bouhnik \& Deshen, 2014; Yeboah

\& Ewur, 2014; Church \& de-Oliviera, 2013). WhatsApp is the most popular mobile messaging application widely used worldwide and is ranked as the number one in terms of monthly active users, based on a study of over 22,500 sources worldwide (Statista, 2018).

WhatsApp features include;

- Text - simple and reliable;

- Group Chat - keeping in touch with love ones, people in your network, business partners, and parishioners;

- $\quad$ On the Web and Desktop - keeping the conversation going anytime, anyplace, anywhere;

- Voice and Video Calls - free face-to-face conversation, when voice and text are not enough;

- $\quad$ End-to-End Encryption - provides security by default;

- $\quad$ Photos and Videos - opportunity to share moments that matter;

- Voice Messaging - using the voice messaging system to convey emotional moments; and

- Documents - attaching and sharing documents including PDFs, spreadsheets, slideshows, photos, and Word documents (http://www.whatsapp.com/features/).

WhatsApp Messenger features make it easy for teaching and learning. The app uses phone internet connections $(4 \mathrm{G} / 3 \mathrm{G} / 2 \mathrm{G} / \mathrm{EDGE}$ of $\mathrm{Wi}-\mathrm{Fi})$ of users to send and receive messages. That is, as long as there is data on users' phones, sending and receiving messages are free. (https://faq. whatsapp.com/en/android/20965922/). WhatsApp announced in May 2018 at its F8 developer conference in San Jose, California, that over 65 billion messages have been sent by users with more than 2 billion minutes of voice and video calls made everyday on the app platform, and about 1 billion people uses this messaging app each day (Al-Heeti, 2018).

Though few studies have researched into the educational benefits of the WhatsApp Messenger platform; students at the university level have used the texting feature to send and receive short messages through mobile devices; institutions of higher learning are gradually adopting WhatsApp for educational purposes; and discussion forums that are prominent in Learning Management Systems (LMS) are also available on some mobile learning platforms such as WhatsApp Messenger (Chan, 2005; Johnson, 2007, Smith, Salaway, \& Caruso, 2009).

\subsection{Key Players of the Ontology}

Effective distance learning program requires inter-relationships among key players. This section identifies four important key players, which include: students, faculty, support staff, and administrators (Barry, 1992). Brian Kathman (2017) posited that, higher education institutions are engaging students more and more through text messaging and fostering of one-to-one relationships. In the past, distance learning students were not as able to freely interact with each other to share their backgrounds and interests. However, new technologies are bringing students together and helping to build communities of learners through distance education (Barry, 1992, pp. 30-32). According to Bernard Bull (2013), faculty acts as tour guides by directing and redirecting the attention of learners toward key concepts and ideas in teaching and learning. Barry Willis (1992) described the support staff as "silent heroes of a successful distance education program" (p. 37).

The support staff assist in promoting persistence and participation to avoid students' dropout. Their services include academic, administrative, and technological support. In most institutions, the support staffs' services are offered through extended hours (Moisey \& Hughes, 2008). Regarding administrators, Barry Willis (1992), indicated that their duties include, planning for technological resources, deploying manpower resources, financial and the necessary capital expenditures to enhance the institution's online learning mission. They also "lead and inspire faculty and staff in overcoming obstacles that arise. Most importantly, they maintain an academic focus, realizing that meeting the instructional needs of distant students is their ultimate responsibility" (Barry, 1992, p. 38). 
Factors that plague online learners in Ghana are many, including; computer illiteracy, access, long-term power outages, and connectivity. Relevant skills deficiency hinders successful facilitation of online learning through discussion boards, timely response to students, and promotion of active learning strategies. "Online instructors specifically need to be able to facilitate online discussions that are rich and meaningful, respond in a timely manner, and model active learning strategies" (Burns, 2011 p. 87). However, universities in Ghana lack the appropriate infrastructure to offer courses online, thereby resorting to face-to-face tutorial sessions in the form of tutorial center operations throughout the country by using untrained tutors who have little or no experience in distance learning. Students who are enrolled in the distance learning programs have to attend tutorials every weekend or bi-weekly.

\section{THE CONTEXT}

\subsection{Description of the Ontology}

This paper used qualitative approach, framed under the paradigm which postulates that reality is relative and depends on multiple systems for meaning. On-to-logy, a Greek word, relates to the nature of reality as seen in the lens of a person in his experiences, this experience may lead the individual to seek meaning. There are two schools of thoughts: the objectivist and subjectivist. The objectivist approach correlates with a quantitative research paradigm, while the subjectivist approach sees the world as socially constructed - a qualitative paradigm (Hudson \& Ozanne, 1988; Lincoln \& Guba, 1985; Neuman, 2000; Bogdan \& Biklen, 2006; Corbin \& Strauss, 2008; Creswell, 2014).

In a typical university distance learning classroom in Ghana; there are students who come directly from the Senior High Schools (17 to 21 year olds); Top-up students ( $21-27$ year olds) coming from the nation's Polytechnics, Colleges of Education, and diploma (or associate) degree programs who enrol into the universities for degree purposes; mature students who are permitted to enrol into university degree programs after attaining the age of 25 (25 - 40 year olds); and similar age groups who are workers and are seeking university degrees for professional advancements. A vast majority of these students live in the nation's hinterlands and are not able to take full advantage of online learning due to factors beyond their control.

This paper describes an ongoing research study, which began in January 2017, about how to create an effective distance learning program in a hybrid mode that integrates WhatsApp Messenger as the learning platform for students who live in Ghana's remote areas where connectivity and electrical power supply are limited. The purpose was to better understand the application of WhatsApp Messenger by using its features to construct meaning for learners and instructors in an online learning context. The study was based in a university in Ghana with three campuses and two learning centers with total student population of about 10,000. Demographic characteristics of the sample participants in the study consisted of 807, composed of 58 percent males and 42 percent females. Students above the age of 25 formed the dominant age group for the study, scoring a total of 83 percent. Sixty percent of the students were married with about 44 percent indicating that about 4 persons depend on them for their sustenance. About 51 percent of the students indicated that they entered the university with other qualifications apart from associate degree or high school diploma. Concerning commitment to study, about 89 percent of the students indicated that they work, while about 54 percent of them were engaged in full time employment. Forty-three percent of the students in the study were committed to study for about ten hours a week.

\section{BLENDED MOBILE LEARNING STRUCTURE}

I present in Table 1, a mobile learning structure indicating a summary comparison between a typical Learning Management System (LMS) and the proper application of the use of WhatsApp as mobile learning platform in a Ghanaian context. The following assumptions were made to explain table 1:

Assumption \# 1

Why it will not work

a) WhatsApp Messenger as a social media tool is not fit for the classroom - for learning purposes. 
b) A typical LMS delivers courseware over the internet - lack of internet connectivity and prolonged power outages in Ghana, especially, in the countryside makes it impossible to sustain online learning. Therefore, LMS will not work for students in Ghana who live far away from the cities.

Assumption \# 2

How it will work

a) For WhatsApp to function properly in online learning environment, the features must be properly integrated to fit the purpose of teaching and learning in a mobile learning context.

b) WhatsApp Messenger uses phone internet connections of users to send and receive messages. That is, as long as there is data on users' phones, sending and receiving messages are free. Therefore, students in Ghana, who live far from the cities can also access online learning benefits through mobile devices.

Jurado, Pattersson, Regueiro-Gomez, and Scheja, (2014), classified learning management systems features into four different tool groups, namely: distribution, communication, interaction, and administration.

1. Tools for distribution allow lecturers to upload documents, available to students. Earlier it was mainly text documents and today it may also be different kinds of media files. Nevertheless, the process is still one-way, that is, teacher-to-learner distribution of information.

2. Tools for communication allow information to go either way as well as from student-to-student. The most common example is E-mail.

3. Tools for interaction call for reaction and feedback. Discussion boards are the most typical example. These tools are of great interest since they may promote student activity and cooperation, hence enhancing the learning experience.

4. Tools for course administration are used to monitor and document the educational process, rather than to facilitate teaching or learning (p.4).

Table 1. Mobile Learning Structure Using WhatsApp Messenger - Ghanaian Context

\begin{tabular}{|c|c|c|c|c|}
\hline $\begin{array}{l}\text { Application: } \\
\text { Online } \\
\text { learning tools. } \\
\text { Jurado, et al., } \\
(2014)\end{array}$ & $\begin{array}{l}\text { Key Players: } \\
\text { Students/faculty } \\
\text { / support staff/ } \\
\text { administrators }\end{array}$ & $\begin{array}{l}\text { Purpose: } \\
\text { Teaching and } \\
\text { learning using } \\
\text { blended mode } \\
\text { of online } \\
\text { learning }\end{array}$ & $\begin{array}{l}\text { Learning Management } \\
\text { System (LMS): } \\
\text { Why LMS will not } \\
\text { work in Ghana due to } \\
\text { lack of Internet Access }\end{array}$ & $\begin{array}{l}\text { WhatsApp Messenger for } \\
\text { Learning: } \\
\text { How WhatsApp will work despite } \\
\text { lack of Internet Access in Ghana }\end{array}$ \\
\hline Distribution & $\begin{array}{l}\text { 1. Faculty } \\
\text { 2. Student } \\
\text { Interaction flows } \\
\text { from teacher to } \\
\text { student }\end{array}$ & $\begin{array}{l}\text { One-way: } \\
\text { from teacher } \\
\text { to student - } \\
\text { one way } \\
\text { process }\end{array}$ & 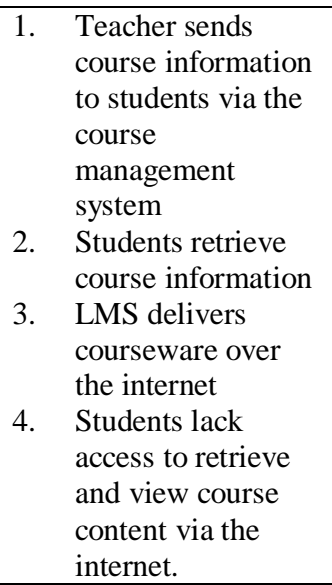 & $\begin{array}{l}\text { 1. } \begin{array}{l}\text { Teacher sends course } \\
\text { information via PDFs or Word } \\
\text { document attachments to } \\
\text { students }\end{array} \\
\text { 2. } \begin{array}{l}\text { Students sign their name } \\
\text { (forum signature) before each }\end{array} \\
\text { WhatsApp post; } \\
\text { 3. Students retrieve course } \\
\text { information } \\
\text { 4. WhatsApp Messenger uses } \\
\text { phone internet connections } \\
\text { 5. As long as there is data on } \\
\text { students' phones, viewing } \\
\text { course content is possible. }\end{array}$ \\
\hline $\begin{array}{l}\text { Communicati } \\
\text { on }\end{array}$ & $\begin{array}{l}\text { 1. Faculty } \\
\text { 2. Student } \\
\text { Interaction flows } \\
\text { both ways }\end{array}$ & $\begin{array}{l}\text { Information } \\
\text { go either } \\
\text { way. } \\
\text { Teacher to } \\
\text { student, } \\
\text { student to } \\
\text { teacher }\end{array}$ & 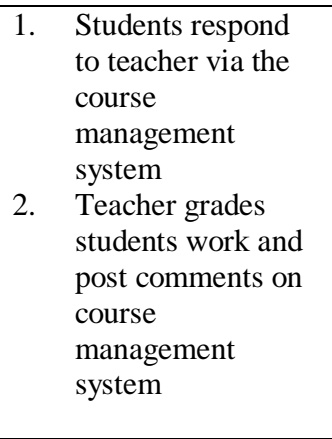 & $\begin{array}{l}\text { 1. Students post completed } \\
\text { assignments in more than one } \\
\text { format via: } \\
\text { a. PDF or Word } \\
\text { attachments } \\
\text { b. Direct text message } \\
\text { 2. Teacher grades students work } \\
\text { and post comments via } \\
\text { WhatsApp Messenger } \\
\text { 3. Teacher sends transcripts of } \\
\text { WhatsApp communication to } \\
\text { course administrators. }\end{array}$ \\
\hline
\end{tabular}




\begin{tabular}{|c|c|c|c|c|}
\hline Interaction & $\begin{array}{l}\text { 1. Students } \\
\text { Peer interactions. } \\
\text { Student to student }\end{array}$ & $\begin{array}{l}\text { Discussion } \\
\text { boards, } \\
\text { students } \\
\text { reactions } \\
\text { and } \\
\text { feedbacks. }\end{array}$ & 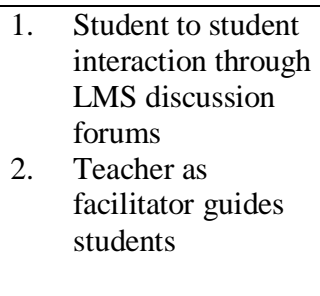 & $\begin{array}{l}\text { 1. Students to student interaction } \\
\text { through: } \\
\text { a. WhatsApp 'group- } \\
\text { chat' } \\
\text { b. Possible video and } \\
\text { voice calls } \\
\text { 2. Teacher as facilitator guides } \\
\text { students }\end{array}$ \\
\hline $\begin{array}{l}\text { Course } \\
\text { Administratio } \\
n\end{array}$ & $\begin{array}{l}\text { 1. Support Staff } \\
\text { 2. Administrators } \\
\text { Back-end } \\
\text { interaction }\end{array}$ & $\begin{array}{l}\text { Course } \\
\text { monitoring, } \\
\text { managemen } \\
\text { t, } \\
\text { documentati } \\
\text { on, and } \\
\text { evaluation. }\end{array}$ & $\begin{array}{l}\text { 1. } \begin{array}{l}\text { Teacher setup the } \\
\text { courses via the }\end{array} \\
\text { LMS } \\
\text { 2. } \begin{array}{l}\text { Teacher post } \\
\text { course syllabus } \\
\text { and assignments } \\
\text { for class } \\
\text { discussions }\end{array} \\
\text { 3. Teacher grades } \\
\text { students work and } \\
\text { post grades online } \\
\text { 4. } \begin{array}{l}\text { Students perform } \\
\text { teacher and course } \\
\text { evaluations online }\end{array}\end{array}$ & 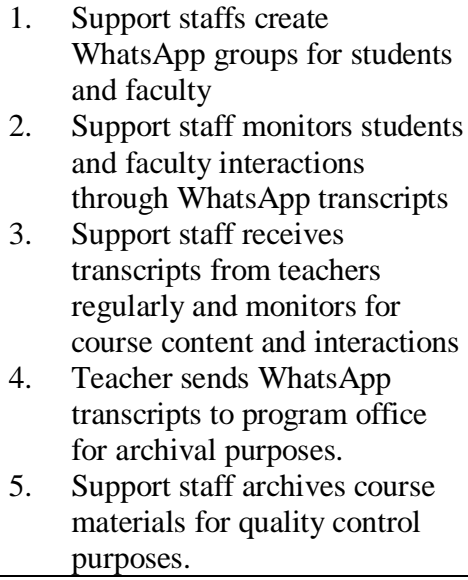 \\
\hline
\end{tabular}

\section{DISCUSSION AND CONCLUSION}

\subsection{Discussion}

This paper depicted an ontology of an ongoing research study. The purpose of the research was to better understand the application of WhatsApp Messenger by using its features to construct meaning for learners and instructors in a blended mobile online learning context. The study was based in a university in Ghana with three campuses and two learning centers with total student population of about 10,000. A sampled total of 807 students from three campuses and two learning centres of the university adopted the use of WhatsApp Messenger in a blended online learning mode.

Total sample size for the study was 807 , composed of 58 percent male and 42 percent female. Students above the age of 25 formed the dominant age group for the study, scoring a total of 83 percent. Sixty percent of the students were married with about 44 percent indicating that about 4 persons depend on them for their sustenance. About 51 percent of the students indicated that they entered the university with other qualifications apart from associate degree or high school diploma.

Concerning commitment to study, about 89 percent of the students indicated that they work, while about 54 percent of them were engaged in full time employment. Forty-three percent of the students in the study were committed to study for about ten hours a week. The results from the demographics report fit traditional adult learners as described in the literature. According to Ross-Gordon (2011), adult students, referred to as - non-traditional students form sizeable presence on university campuses and also constitute a substantial share of the undergraduate student body. The National Center for Educational Statistics (NCES, 2009) survey reported that 38 percent of student enrolment for the 2007 academic year were 25 years of age or older. Choy (2002) cited the 2002 NCES statistics that defined seven characteristics of non-traditional students as follows:

1. Entry to college delayed by at least one year following high school,

2. Having dependents,

3. Being a single parent,

4. Being employed full time,

5. Being financially independent, 
6. Attending part time, and

7. Not having a high school diploma.

Ross-Gordon (2011) described characteristics that separate re-entry adults from other traditional university students to be; "the high likelihood that they are juggling other life roles while attending school, including those of worker, spouse or partner, parent, caregiver, and community member" (p. 27).

\subsection{Conclusion}

In designing the blended mobile learning structure, I applied agile methodologies using WhatsApp Messenger as a learning platform, that meets the current infrastructural conditions in Ghana.

Seth Earley (2017), stated that, there must be the need to interpret user signals accurately to "enable the system to present the right content for the user's context," this may "require not only that our customer data is clean, properly structured, and integrated across multiple systems and processes but also that the system understand the relationship between the user, his or her specific task, the product, and the content needed" (pp. 58-64).

According to Yeboah and Ewur (2014), the adoption of WhatsApp in the classroom is anathema. To them, the technology is nuisance to university students. They concluded that, "if students bring their mobile phones to class, they get bored of the lesson and find their way onto WhatsApp. These detracts their attention from the main lesson, and are not able to fully understand what is going on, hindering participation and drawing them even further into WhatsApp making it more difficult for them at the end of the day" (p. 162).

Contrary to Yeboah and Ewur's, assertions, the current paper has proven otherwise. In this study, I made several assertions that, for WhatsApp to work properly in any classroom in Ghana, there must be intentional designs and step-by-step approach to teach both the faculty and the students how to use the application to achieve the utmost outcomes (see table 2, above). Because, I believe that, "seemingly intractable problems have been solved by advances in processing power and capabilities. Not long ago, autonomous vehicles were considered technologically infeasible due to the volume of data that needed to be processed in real time. Speech recognition was unreliable and required extensive speaker-dependent training sessions. Mobile phones were once "auto-mobile" phones, requiring a car trunk full of equipment" (Earley, 2017, pp. 58-64).

\section{REFERENCES}

Al-Heeti, A. (2018). WhatsApp: $65 B$ messages sent each day, and more than $2 B$ minutes of calls. C/net News. Retrieved on July 14, 2018, from: https://www.cnet.com/news/whatsapp-65-billion-messages-sent-each-day-and-more-than-2billion-minutes- of-calls/

Barry, W. (1992). Effective distance education: A primer for faculty and administrators. Monograph Series in Distance Education No. 2. Fairbanks, Alaska

Bogdan, R. \& Biklen, S. K. (2006). Qualitative Research for Education: An Introduction to Theories and Methods. 5th ed. London, UK: Pearson.

Bouhnik, D. \& Deshen, M.(2014). Whatsapp goes to school: Mobile instant messaging between teachers and students. Journal of Information Technology Education: Research, 13:217-231.

Bull, B. (2013). Eight roles of an effective online teacher. Higher Education Teaching Strategies from Magna Publications: Faculty Focus. Retrieved on July 18, 2018, from: https:/www.facultyfocus.com/articles/onlineeducation/eight-roles-of-an-effective-online-teacher/

Burns, M. (2011). Distance education for teacher training: Modes, models, and methods. Education Development Center Inc. Washington, DC.

Carson, D., Gilmore, A., Perry, C., \& Gronhaug, K.(2001). Qualitative Marketing Research. London: Sage.

Cetinkaya, L.(2017). The impact of WhatsApp use on success in education process. The International Review of Research in Open and Distributed Learning. 18(7). 10.19173/irrodl.v18i7.3279.

Chan, L.(2005). WebCT revolutionized e-learning. UBC Reports, 51(7).

Church, K. \& de Oliveira, R.(2013). "What's up with WhatsApp? Comparing mobile instant messaging behaviors with traditional SMS." In Proceedings of the 15th International Conference on Human-Computer Interaction with Mobile Devices and Services (MobileHCI), Munich, Germany, pp. 352-361. 
Choy, Susan.(2002). Findings from the Condition of Education 2002: Nontraditional Undergraduates. Washington, DC: National Center for Education Statistics. http://nces.ed.gov/programs/coe/2002/analyses/nontraditional/index.asp.

Corbin J, Strauss A.(2008). Basics of Qualitative Research: Techniques and Procedures for Developing Grounded Theory. 3rd ed. Thousand Oaks, CA: SAGE Publications; eds.

Creswell, J. W. (2014). Research design: Qualitative, quantitative, and mixed methods approaches (4rd ed.). Los Angles: Sage.

Earley, S.(2017). There's no AI (artificial intelligence) without IA (information architecture). IT Professionals 18(3). 58 - 64. Doi: 10.1109/MITP.2016.43.

Gronlund, Å., \& Islam, Y. (2010). A mobile e-learning environment for developing countries: The Bangladesh virtual interactive classroom. Information Technology for Development, 16(4), 244-259. doi:10.1080/02681101003746490.

Hudson, L. \& Ozanne, J.(1998). Alternative Ways of Seeking Knowledge in Consumer Research. Journal of Consumer Research, 14(4), 508-521.

Johnson, G. M. (2007). College student internet use: convenience and amusement. Canadian Journal of Learning and Technology, 33(1).

Joy Online.(2013). Increase use of smartphones made Ghana No-1in mobile broadband penetration. Retrieved from: business.myjoyonline.com/pages/news/201301/99976.php.

Jurado, R. G., Pattersson, T., Regueiro-Gomez, A. \& Scheja, M. (2014). Classification of the feature in learning management

systems. XVII Scientific Convention on Engineering and Architecture, Havana City, Cuba, Nov 24th - 28. Conference Paper.

Kathman, B. (2017). 3 biggest trends impacting higher education communication this year. Higher Education Technology: SignalVine. Retrieved on July 18, 2018, from: https://www.signalvine.com/higher-educationcommunication-trends/ .

Laary, D. (2016). Ghana: Mobile phone penetration soars to 128\%. The Africa Report. Retrieved from: www.theafricareport.com/West-Africa/ghana-mobile-phone-penetration-soars-to-128.html.

Larkai, A. T., Ankomah-Asare, E. T. \& Nsowah-Nuamah, N. N. N. (2016). Distance education in Ghana: An overview of enrolment and programme patterns. Proceedings of INCEDI 2016 Conference, Accra, Ghana; 184 - 190.

Lincoln, Y., and Guba, E. (1985). Naturalistic Inquiry. London: Sage.

Löfgren, K. (2013). What is ontology? Introduction to the word and the concept. Examily. Retreived on July 14, 2018, from: https://examily.com/article/what-is-ontology-introduction-to-the-word-and-the-concept-10090.

Moisey, S. \& Hughes, J. (2008). Supporting the Online Learner. In: Anderson, T. (Ed.), The Theory and Practice of Online Learning, 12nd ed., AU Press: Athabasca, Alberta, 419-432.

Motlik, S. (2008). Mobile learning in developing nations. Technical Evaluation Report. The International Review of Research in Open and Distance Learning, 63, 9(2). Retrieved from http://www.irrodl.org/index.php/irrodl/article/viewArticle/564/1039.

National Center for Education Statistics (NCES, 2007). Total fall enrollment in degree-granting institutions by control and type of institution, age, and attendance status of student: Digest of Educational Statistics 2009. Table 192.2007. http://nces.ed.gov/programs/digest/d09/tables/dt09_192.asp?referrer=list (2009).

Neuman, L. W. (2000). Social research methods: Qualitative and quantitative approaches (4 $4^{\text {th }}$ Ed.), USA: Allyn and Bacon.

Pew Research Center Surveys. (2015). Spring 2014 global attitudes survey: Q68. Retrieved from: www.pewglobal.org/2015/04/15/cell-phones-in-Africa-communication-lifeline/ (2015).

Quin, C. (2002). mLearning: mobile, wireless, in-your-pocket learning. /L1 = LQH, Fall (2002).

Ross-Gordon, J.M. (2011). Research on adult learners: Supporting the needs of a student population that is no longer nontraditional. Peer Review, 13(1), 26-29.

Sener, J. (2015). Definitions of e-learning courses and programs version 2.0 April 4, 2015. Updated E-Learning Definitions. Available at: http://onlinelearningconsortium.org/updated-e-learning-definitions-2/ (2015).

Sloan Consortium. (2008). Staying the course: Online education in the United States. Wellesley, MA: Babson College.

Smith, S. D., Salaway, G., \& Borrenson C. J. (2009). The ECAR study of undergraduate students and information technology, EDUCAUSE Center.

Statista (2018). Most popular mobile messaging apps worldwide as of April 2018, based on number of monthly active users (in millions). The Statistics Portal. Available at: https://www.statista.com/statistics/258749/most-popularglobal-mobile-messenger-apps/.

UNESCO (2013). UNESCO policy guidelines for mobile learning. Paris, France. ISBN 978-92-3-001143-7.

Yeboah, J. \& Ewur, G. D. (2014). The impact of WhatsApp Messenger usage on students performance in tertiary institutions in Ghana. Journal of Education and Practice 5(6) 157 - 164. 